\title{
ANALYSIS OF GAMMA HEATING AT TRIGA MARK REACTOR CORE BANDUNG
} USING PLATE TYPE FUEL

\author{
Setiyanto and Tukiran Surbakti \\ Center for Nuclear Reactor Technology and Safety - Batan \\ GD. 80 Puspiptek area, Tangerang Selatan, Banten, Indonesia \\ E-mail: setia@,batan.go.id \\ Diterima editor: 12 Agustus 2016 \\ Diperbaiki: 14 September 2016 \\ Disetujui untuk publikasi: 16 September 2016
}

\begin{abstract}
ANALYSIS OF GAMMA HEATING AT TRIGA MARK REACTOR CORE BANDUNG USING PLATE TYPE FUEL. In accordance with the discontinuation of TRIGA fuel element production by its producer, the operation of all TRIGA type reactor of at all over the word will be disturbed, as well as TRIGA reactor in Bandung. In order to support the continuous operation of Bandung TRIGA reactor, a study on utilization of fuel plate mode, as used at RSG-GAS reactor, to replace the cylindrical model has been done. Various assessments have been done, including core design calculation and its safety aspects. Based on the neutronic calculation, utilization of fuel plate shows that Bandung TRIGA reactor can be operated by 20 fuel elements only. Compared with the original core, the new reactor core configuration is smaller and it results in some empty space that can be used for in-core irradiation facilities. Due to the existing of in-core irradiation facilities, the gamma heating value became a new factor that should be evaluated for safety analysis. For this reason, the gamma heating for TRIGA Bandung reactor using fuel plate was calculated by Gamset computer code. The calculations based on linear attenuation equations, line sources and gamma propagation on space. Calculations were also done for reflector positions (Lazy Susan irradiation facilities) and central irradiation position (CIP), especially for any material samples. The calculation results show that gamma heating for CIP is significantly important $(0,87 \mathrm{~W} / \mathrm{g})$, but very low value for Lazy Susan position (lest then $0,11 \mathrm{~W} / \mathrm{g}$ ). Based on this results, it can be concluded that the utilization of CIP as irradiation facilities need to consider of gamma heating as data for safety analysis report.
\end{abstract}

Keywords: gamma heating, nuclear reactor, research reactor, reactor safety.

\begin{abstract}
ABSTRAK
ANALISIS PANAS GAMMA PADA TERAS REAKTOR TRIGA MARK BANDUNG BERBAHAN BAKAR TIPE PELAT. Dengan dihentikannya produksi elemen bakar reaktor jenis Triga oleh produsen, maka semua reaktor TRIGA di dunia terganggu operasinya, termasuk juga reaktor TRIGA 2000 di Bandung. Untuk mendukung pengoperasian reaktor TRIGA Bandung, telah dilakukan kajian penggunaan bahan bakar jenis pelat seperti yang digunakan oleh RSG-GAS. Berbagai langkah analisis telah disiapkan, termasuk perhitungan desain teras, dan sistem keselamatannya. Penggunaan elemen bakar tipe pelat menghasilkkan reaktor dapat dioperasikan hanya dengan 20 elemen bakar. Dibandingkan teras aslinya, nampak bahwa teras baru menjadi lebih kecil dan kompak, rapat dayanya naik, tetapi menyisakan beberapa ruang kosong yang dimungkinkan untuk menempatkan fasilitas iradiasi di teras. Dengan adanya fasilitas iradiasi di dalam teras, maka pembangkitan panas gamma di teras menjadi faktor baru yang harus diperhatikan. Untuk alasan ini, telah dilakukan perhitungan pembangkitan panas gamma teras reaktor Triga 2000 Bandung mengunakan program Gamset. Perhitungan didasarkan pada persamaan atenuasi liner, sumber garis dan arah perambatan tiga dimensi. Selain panas gamma di teras, akan dihitung juga panas gamma di reflektor (Lazy Susan), dan di CIP untuk berbagai jenis bahan. Diperoleh hasil bahwa panas gamma di CIP cukup signifikan (0,87 w/g), tetapi di posisi Lazy Susan relatif kecil, rata-rata hanya 0,11 w/g. Dari hasil tersebut dapat disimpulkan bahwa penggunaan CIP untuk iradiasi perlu mempertimbangkan panas gamma dalam perhitungan LAK nya.
\end{abstract}

Kata kunci: panas gamma, reaktor nuklir, reaktor penelitian, keselamatan reaktor 


\section{INTRODUCTION}

The Triga 2000 Bandung Research reactor is a TRIGA MARK II type reactor, that has been upgraded several times. Starting from the first time, the reactor was operated at a power of $250 \mathrm{~kW}$, then upgraded to $1 \mathrm{MW}$ at 1971 . Due to the demands for research and radioisotope production, reactor power was upgraded again to $2 \mathrm{MW}$ in 2000. Since the beginning operation up to now, in which reactor operated at $2 \mathrm{MW}$ of power, the reactor uses cylinder (tube) types of uraniumzirconium-hybrid ( $\mathrm{UZrH})$ fuel elements made by General Atomic - Cerca. Due to the termination of the fuel element production by the manufacturer, all TRIGA MARK reactors in the world can not continuously be operated, including TRIGA 2000 Bandung. Various attempts have been done, including the possibility of using of plate-type fuel elements made by PT. Inuki. The performances of this fuel element are really very good because it has been used for over of 25 years in the RSGGAS reactor without any problems. The utilization of this fuel type for TRIGA reactor finally was followed up with various analysis, including core design calculations, coolant systems analysis and any other analysis for safety related aspects [1-3]

The utilization of plate type fuel element allows a core configuration to be very compact (small), only uses of 20 fuel elements arranged on the rectangular of 5 x 5 matrix configuration. Compared with the original core, this new configuration allows for several irradiation facilities in the core [1-3]. This new compact core configuration also has the possibility increasing of reactor power density, as well as the gamma heating value accordingly. This condition gives the gamma heating generation in core becomes a new factor that must be considered $[1,4]$. The gamma heating is important data for preparing the safety analysis report of any materials will be irradiated at reactor core.

This paper presents the calculation and analysis of gamma heating generation of TRIGA 2000 reactor core, which is done by using the analytic approach using Gamset code. Each fuel element considered as gamma line source, where the gamma intensity concentrated at the center of the fuel element. The Gamset code itself has proven its validity in the RSG-GAS, so with the use of the same fuel element, then use Gamset code becomes very relevant [4-6]. Besides gamma heating at the core, the calculation was done also at reflector (Lazy Susan), in where the cylindrical shape of the reflector will be modeled into rectangular pieces like fuel elements $(8.1 \times 7.71) \mathrm{cm}$. Due to the lack of gamma heating data at previous core configuration, all data are obtained by this calculations very useful to fulfill the core characteristic of TRIGA reactor.

\section{THEORY}

\section{Gamset Code}

The Gamset code is a computer program of gamma heating calculation in the nuclear reactor core, which the calculations are based on the linear attenuation equations. The intensity of gamma absorbed in any part of the material is a part of the heating source in this material its self. The gamma radiation in the core came from the prompt fission reaction, gamma decayed from fission production and also from gamma radiation from a neutron capture of each material in the core. Those gamma radiations called 'core gamma source' radiate in all directions around the reactor core. For simplification, all the gamma radiations are assumed from every fuel element, which each fuel element assumed as a gamma source. All gammas in each fuel element are supposed on the centered axis of the fuel as a line source. To take into account of various gamma energies, we assumed that the entire of gamma energy is grouped into three (3) groups of $0.1 \mathrm{MeV}, 0.5 \mathrm{MeV}$ and $1.5 \mathrm{MeV}[5,7]$. The Gamma radiation is diffused and attenuated on every material, following the linear attenuation equation as follows $[5,8,9,10]$ :

$$
I_{\mathrm{a}}=I_{\mathrm{o}} \cdot\left\{1-\exp \left[-\left(\frac{\mu}{\rho}\right) \cdot \rho \cdot x\right]\right\}=I_{\mathrm{o}} \cdot[1-\exp (-\mu \cdot x)]
$$


where :

$\mathrm{I}_{\mathrm{o}} \quad$ = gamma intensity before attenuated

$\mathrm{I}_{\mathrm{a}} \quad$ = gamma absorbed by material

$(\mu / \rho)=$ mass absorption coefficient from material that is passed, $\left(\mathrm{cm}^{2} / \mathrm{g}\right)$

$\mu \quad=$ absorption coefficient of material $\left(\mathrm{cm}^{-1}\right)$

$\rho \quad=$ material density, $\left(\mathrm{g} / \mathrm{cm}^{3}\right)$.

$\mathrm{x} \quad=$ material thickness $(\mathrm{cm})$

Implementation of gamma energy at group $(i)$ and the type of material that is passed $(j)$ makes the above equation must be:

$$
I_{\mathrm{a}, i}=I_{\mathrm{o}, i} \cdot\left\{1-\sum_{j} \exp \left[-\left(\frac{\mu}{\rho}\right)_{i, j} \cdot \rho_{j} \cdot x_{j}\right]\right\}=I_{\mathrm{o}, i} \cdot\left[1-\sum_{j} \exp \left(-\mu_{i} \cdot x_{j}\right)\right]
$$

This equation is the basic equation on the Games code, which is then applied to the whole fuel and reaches out to every point in the reactor.

\section{Core Model and Configuration of TRIGA 2000 Bandung}

As well as TRIGA reactor in general, the form of the reactor core TRIGA 2000 Bandung is a cylindrical shape, in which the reactor core is surrounded by reflector graphite. The main irradiation facility is located in the reflector using the Lazy Susan device. The changes in the type of fuel from cylindrical to plate shape result in a very significant change in the configuration of the core. By maintaining the utilization of existing graphite reflectors, the neutronics calculations showed an alternative of the equilibrium core configuration, consisting of 20 fuel elements arranged in a $5 \times 5$ grids, including four (4) positions for the control elements and a position in the middle of irradiation (CIP/Central Irradiation Position). The reactor core remains are surrounded by a graphite reflector $[1-3,6]$.

The core configuration on $5 \times 5$ and retaining cylindrical reflectors give a large empty space between the core and the reflector, therefore it can be used for in-core irradiation facilities. This is a significant change comparing to the previous core that does not provide an irradiation facilities other than in the central thimble. The cross section of TRIGA and new core configurations are described in Figure 1 below.
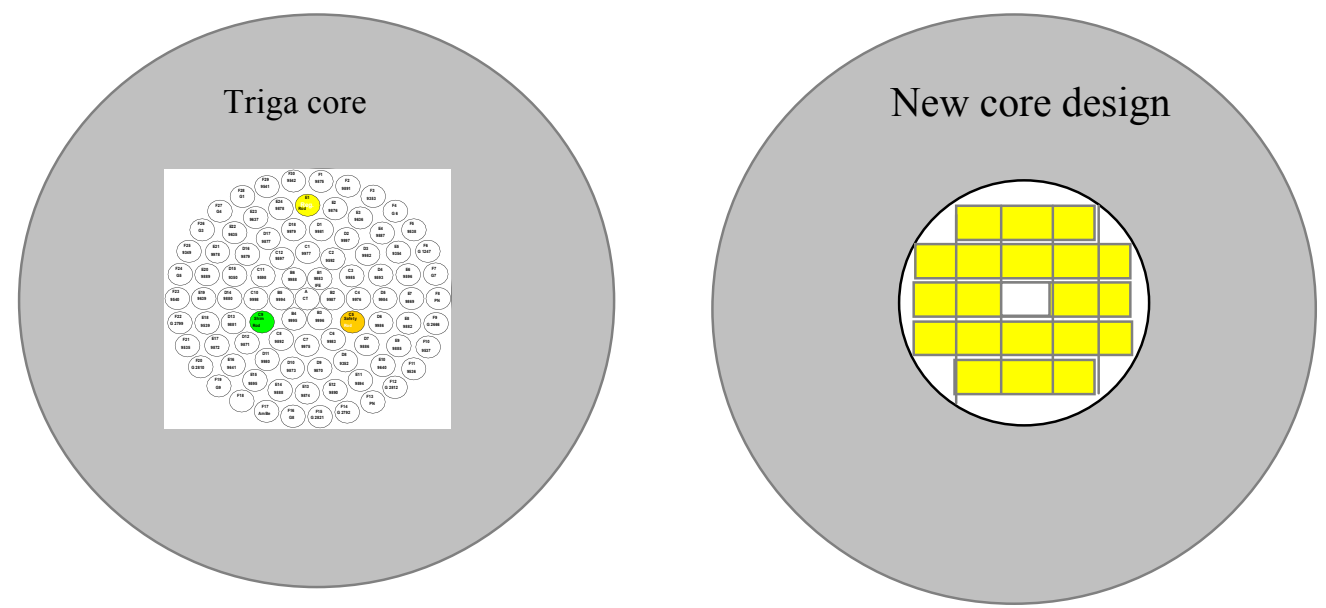

Fig 1. Cross section of TRIGA and new core configurations 


\section{Core Configuration}

The Gamset computer code uses rectangular geometry model so that the shape of the reactor core of TRIGA 2000 Bandung should be transformed from cylinder to a rectangular shape. Figure 2 presents the core and reflector matrix model. It appears that based on the dimensions and size of the core and the reflector, then the core and the reflector is modeled in the form of $20 \times 20$ matrix where each element size adjusted to the size of the fuel used, namely $(8.1 \times 7.71) \mathrm{cm}[1,6]$.

The position of the matrix elements in Figure 2 is determined from the point $(0,0)$ in the upper left corner, heading to the right (x-axis) and down as the y-axis. For example, the CIP is at the coordinate position (10.09).

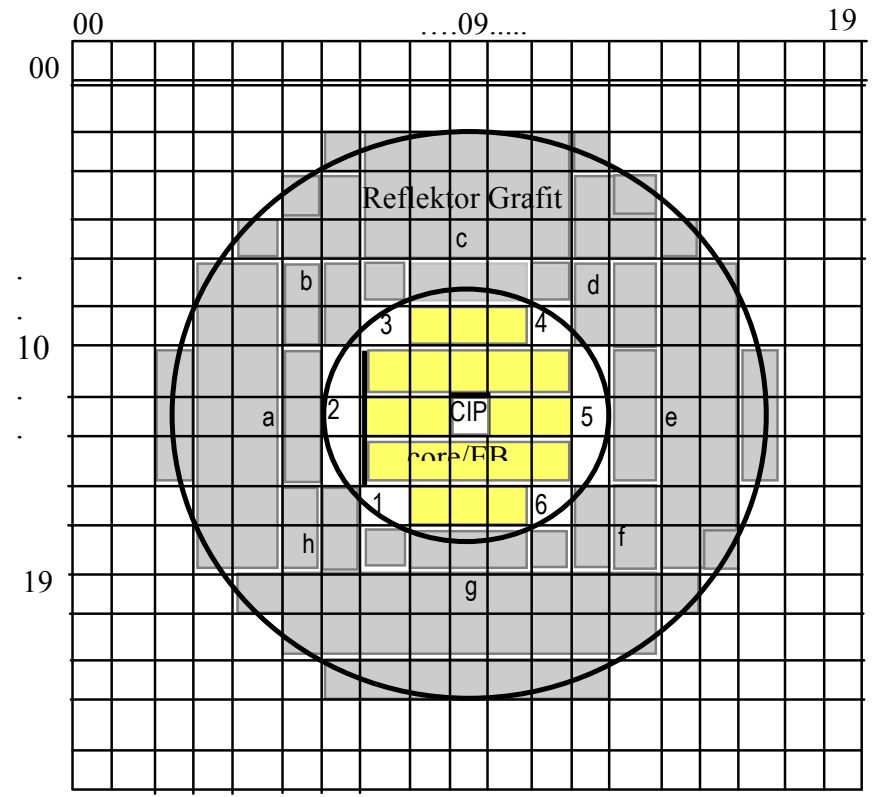
Dwater
$\square$ Core, fuel
$\square$ Graphite reflectorReflektor
$1,2 \ldots 6$ : irradiation position
a, b ...h : irradiation position at Lazy
CIP: central irradiation position

Fig 2. Core and reflector matrix model

The configuration can be specified as follows:

a) The active core consist of $5 \times 5$ matrix with the number of fuel element 20 pieces.

b) 6 core positions filled with water can be used for irradiation facilities, the positions are expressed by the number of 1.2, up to 6 in Figure 2

c) Lazy Susan irradiation facility is represented by the position of the code a, b...up to $h$

d) Graphite elements are 120 pieces.

e) CIP is only one position

f) A matrix of water is inside and outside the core and used as a reflector of $20 \times 20$ matrix. Gamma heating can be calculated at any point or position, either in the core or in the reflector.

\section{CALCULATION METHOD}

Gamma heating calculations were done using Gamset code, in which the data is taken from the fuel element uranium oxide with the fuel density data of $2.96 \mathrm{~g} \mathrm{U} / \mathrm{cc}$ as fuel elements in reactor RSG-GAS. Table 1 contains the main data that used in the calculation. 
Table 1. Nuclear data of Uranium Oxide with fuel loading of $2.96 \mathrm{gU} / \mathrm{cc}$. [1,7]

\begin{tabular}{llr}
\hline No & Data & Value \\
\hline 1 & $\sigma($ barn $)$ & 10.25 \\
2 & $\rho(\mathrm{gr} / \mathrm{cc})$ & 3.76 \\
3 & $A(\mathrm{gr} / \mathrm{mol})$ & 40.16 \\
4 & $(\mu / \rho)$ group 1 $\left(\mathrm{cm}^{-1}\right)$ & 0.4867 \\
5 & $(\mu / \rho)$ group 2 $\left(\mathrm{cm}^{-1}\right)$ & 0.0465 \\
6 & $(\mu / \rho)$ group 3 $\left(\mathrm{cm}^{-1}\right)$ & 0.0262 \\
7 & $E_{\gamma}$ group 1 prompt $(\mathrm{MeV})$ & 6.0326 \\
8 & $E_{\gamma}$ group 2 prompt $(\mathrm{MeV})$ & 18.57 \\
9 & $E_{\gamma}$ group 3 prompt $(\mathrm{MeV})$ & 5.3990 \\
10 & $E_{\gamma}$ group 1 delayed $(\mathrm{MeV})$ & 0.0065 \\
11 & $E_{\gamma}$ group 2 delayed $(\mathrm{MeV})$ & 0.0061 \\
12 & $E_{\gamma}$ group 3 delayed $(\mathrm{MeV})$ & 0.0822 \\
13 & $E_{\beta}$ average prompt $(\mathrm{MeV})$ & 173.20 \\
14 & $E_{\beta}$ average delayed $(\mathrm{MeV})$ & 0.06 \\
\hline
\end{tabular}

Figure 2 shows a model of the TRIGA core configuration in a rectangular matrix, it appears that the 20 fuel elements are surrounded by the graphite reflector, some of them are leaving empty positions. Position number of 1,2 ...up to..6 are the positions that can be used for core irradiation facility. While some positions at the reflector given index letters of $a, b$... up to .. $h$ are the irradiation position on the Lazy Susan.

The complete of core and reflector configurations model for Gamset code in the form of rectangular $20 \times 20$ matrix is presented in Table 2.

Table 2. Core configuration and reflector

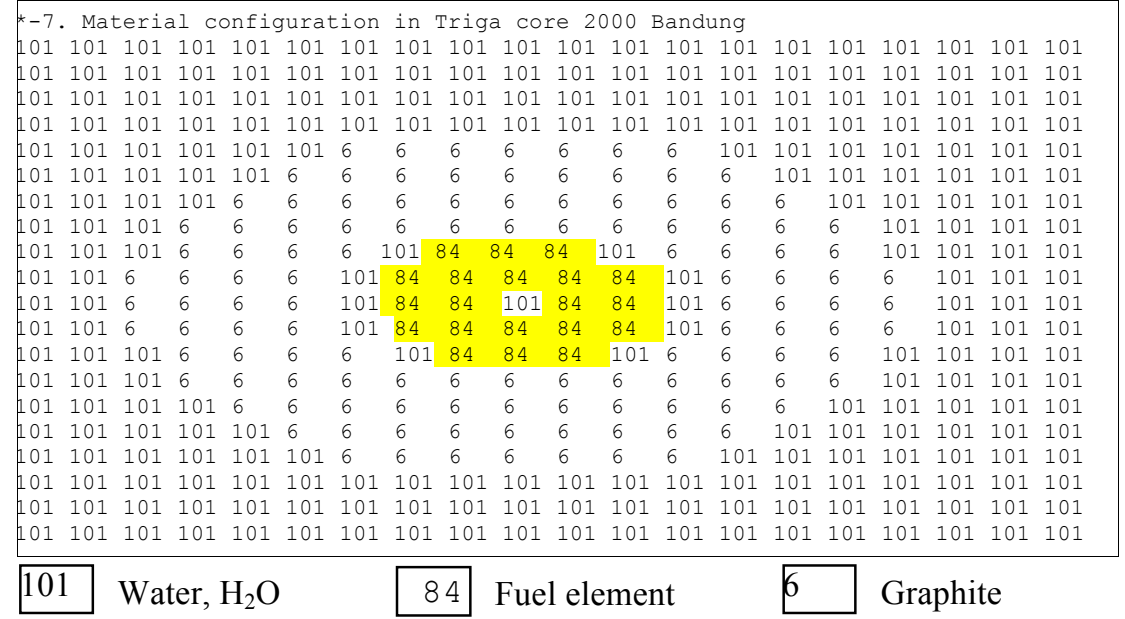

To anticipate the use of various materials which may be irradiated, especially at the CIP, gamma heating calculation is conducted for materials of $\mathrm{Al}, \mathrm{Fe}, \mathrm{Zr}, \mathrm{Pb}$ and $\mathrm{Au}$. Furthermore, the calculation results can be interpolated and extrapolated as a function of material atomic number to get gamma heating value on any material with the atomic number of $\mathrm{Z}$. 


\section{RESULTS AND DISCUSSION}

The results of gamma heating calculation for TRIGA 2000 Bandung reactor using fuel plate type are presented in Table 3 below:

Table 3. Results of gamma heating calculation in the core using plate typed fuel and reflector of TRIGA Bandung at $2 \mathrm{MW}$ of power

\begin{tabular}{|c|c|c|c|}
\hline \multicolumn{4}{|c|}{ Gamma heating in the Triga core Bandung at $2 \mathrm{MW}$ of power } \\
\hline \multicolumn{2}{|c|}{ Position in the core $(\mathrm{W} / \mathrm{g})$} & \multicolumn{2}{|c|}{ Position in the reflector $(\mathrm{W} / \mathrm{g})$} \\
\hline CIP & 0.87 & $\mathrm{a}$ & 0.13 \\
\hline 1 & 0.37 & $\mathrm{~b}$ & 0.09 \\
\hline 2 & 0.31 & $\mathrm{c}$ & 0.1 \\
\hline 3 & 0.37 & $\mathrm{~d}$ & 0.09 \\
\hline 4 & 0.37 & e & 0.15 \\
\hline 5 & 0.32 & $\mathrm{f}$ & 0.11 \\
\hline \multirow[t]{2}{*}{6} & 0.39 & $\mathrm{~g}$ & 0.1 \\
\hline & & $\mathrm{h}$ & 0.09 \\
\hline
\end{tabular}

gamma heating $(\mathrm{W} / \mathrm{g})$

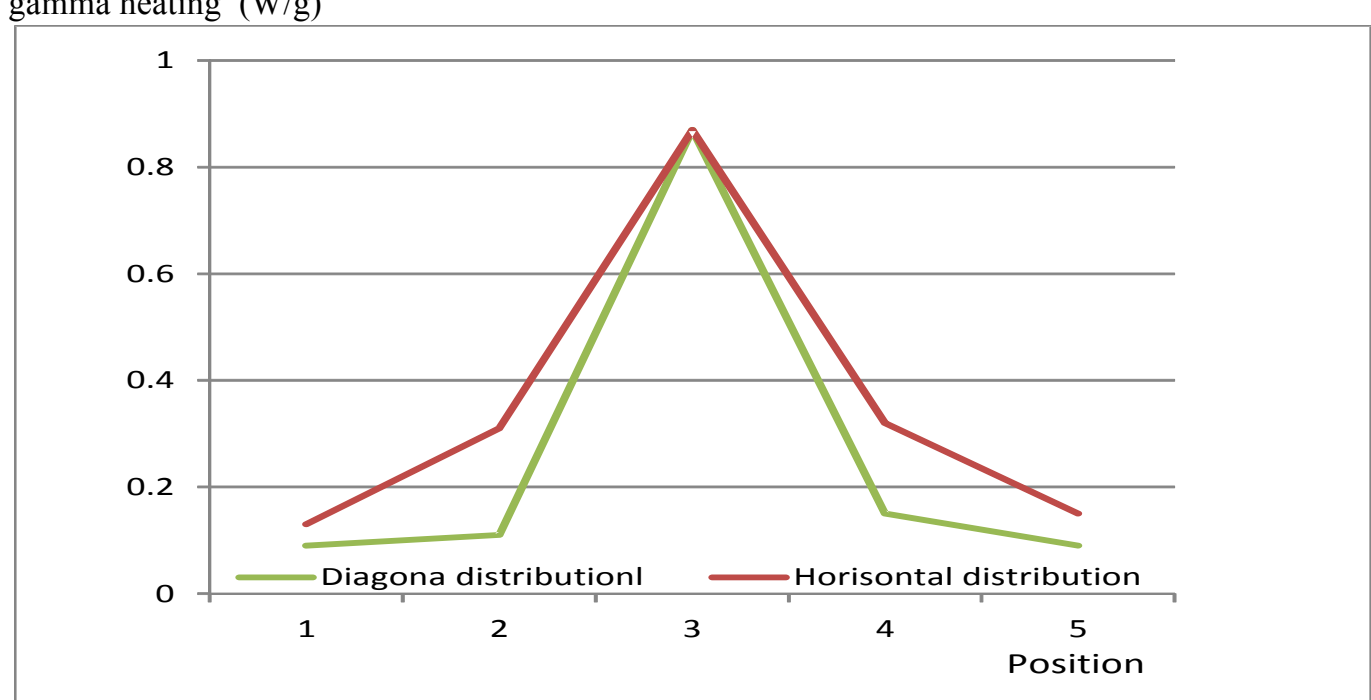

Figure 3. Core gamma heating distribution for horizontal and diagonal direction.

From the calculation results obtained above, we can see that the distribution of gamma heating is a line with neutron flux distribution, the maximum value indicated at the middle core, and decrease as function of distant in the core. It appears that the value of gamma heating in the core and reflector was not so significant (only $0.87 \mathrm{w} / \mathrm{g}$ at the CIP) compared with the high power reactor as the RSG-GAS reactor (which has a gamma heating approximately $8 \mathrm{~W} / \mathrm{g}$ in graphite). However, these values are still important as first information for reactor users. The users can anticipate the quantities of the heat source in their experiment facilities and determine early the heat removal system that should be applied. To avoid the heating accumulation, heat from any source in the material or devices should be removed.

It is noted that the gamma heating value mentioned above, occur only at graphite material, (graphite is an international standard of material for gamma heating measurement). As any 
material can be irradiated at reactor core, we need to know more detail the gamma heating occurs at any material irradiated. Gamset code has the capability to solve these problems, where the calculations were realized for materials represented by an atomic number of Z. By using of 5 materials as calculation sample, the gamma heating at other materials can be determined by interpolation or extrapolation model. Table 4 and/or Figure 4 show the gamma heating value at any material as a function of the material atomic number. All calculations realize for CIP position only.

Table 4. Result of gamma heating calculation for TRIGA reactor using plate typed fuel for $2 \mathrm{MW}$ of power at CIP position for several kinds of material

\begin{tabular}{|c|c|c|}
\hline \multicolumn{3}{|c|}{ Gamma heating for Triga reactor Bandung at CIP positions } \\
\hline Material & Atomic Number & Gamma heating $\mathrm{W} / \mathrm{g}$ \\
\hline $\mathrm{C}$ & 6 & 0.87 \\
\hline $\mathrm{Al}$ & 13 & 0.89 \\
\hline $\mathrm{Fe}$ & 26 & 1.24 \\
\hline $\mathrm{Zr}$ & 40 & 1.77 \\
\hline $\mathrm{Pb}$ & 82 & 2.10 \\
\hline
\end{tabular}

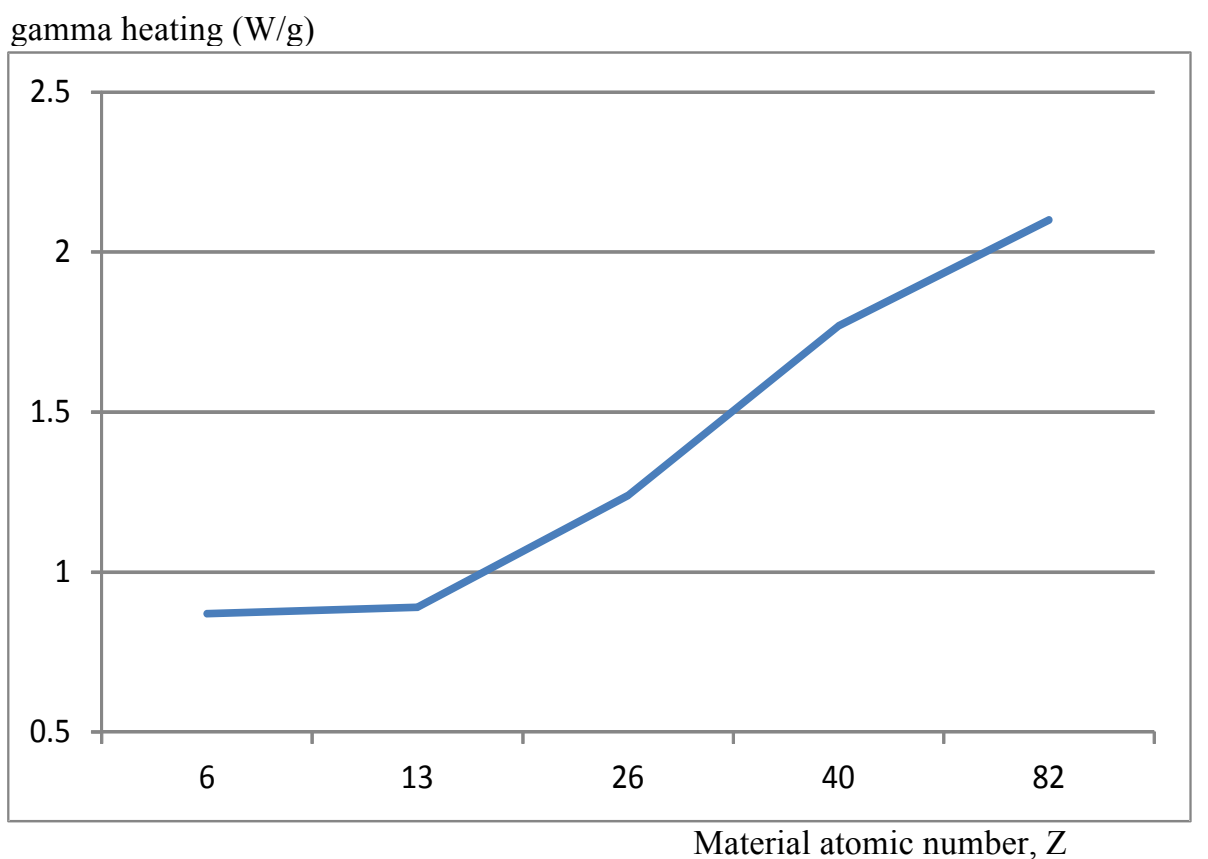

Figure 4. Gamma heating variation for several kinds of material (atom number, Z)

According to gamma heating values presented in Table 4 above, we need to get more attention especially if the SS material or another heavy material irradiated at CIP position, the gamma heating value increase as a function of the material atomic number. For example, if reactor operates at $2 \mathrm{MW}$ of power, the metals dominated by Fe irradiated at CIP has the potential heat generation of $1.25 \mathrm{~W} / \mathrm{g}$. Supposed we irradiated of $10 \mathrm{~g}$ of Fe, it will generate 12.5 watts of heat. This value is equivalent to the power generation of 12.5 Joules per second, or 45,000 Joule within 1 hour. This quantity of heat become significant and mush be considered the heat removal system. The use of other materials will provide varying heat quantity, it will increase or decrease depend on the material atomic number. As shown in Figure 4, the gamma heating will increase as a function of the material atomic number. Finally, if any material or facility will be irradiated at the CIP, it is necessary to consider the gamma heating value for prepare the safety analysis report. 


\section{CONCLUSION}

In this study, the gamma heating at the reactor core of TRIGA 2000 Bandung at 2 MW of power with plate typed fuel elements has been evaluated. The gamma heating at CIP is significant for heavy material $(1,24 \mathrm{~W} / \mathrm{g}$ on Fe material) which it increases significantly as a function of the atomic number). All devices or equipment contain Fe material are inserted to the core mush be completed by safety analysis report (SAR). According to this result, it can be concluded that gamma heating at TRIGA 2000 Bandung reactor using of plate-type fuel elements reactor began important value to be considered as new reactor characteristic, especially for irradiation at CIP position.

\section{REFERENCES}

1. Setiyanto, Estimation and analysis of gamma heating distribution for innovating research reactor core design. Tri Dasa Mega 2014; 16(3):160-168 (in Indonesian).

2. Tukiran $\mathrm{S}$, et al. Conceptual design of innovative research reactor using uranium molybdenum fuel from the neutronic aspect of view. Tri Dasa Mega 2012; 14(3):178-191 (in Indonesian).

3. Lilly Suparlina, et al. Analysis of fuel management pattern on MTR type research reactor core. Tri Dasa Mega 2014; 16(2):89-99 (in Indonesian).

4. Matthieu Lemaire, Claire Vaglio-Gaudard, Abdallah Lyoussi \& Christelle ReynardCarette., For a better estimation of gamma heating in nuclear material testing reactors and associated devices: status and work plan from calculation methods to nuclear data, Journal of Nuclear Science and Technology 2015; 52(9):1093-1101.

5. Maeda, S.; Naito, H.; Soga, T.; Aoyama, T., Gamma Heating Rate Evaluation for Material Irradiation Test in the Joyo Experimental Fast Reactor. Journal of Nuclear Data Sheets 2014; 118:494-497.

6. Pudjijanto MS. and Setiyanto, Modification and validation 'Gamset code'for analysis on gamma heating distribution for an innovating research reactor. Proceeding of National Seminar on Technology of Nuclear Energy; 2015 October 15-16. Denpasar, Indonesia. Vol. 1/2015. p. 357-364.

7. Russell Goff, G-Demption, LLC, Technical Feasibility of Storing 1 Month Old SNF in an Onsite Irradiation Facility - 14233, WM2014 Conference; 2014 March 2 - 6, Phoenix, Arizona, USA; 2014. p. 1-16.

8. Lemaire.M, Vaglio-Gaudard. C, Reynard-Carette. C. For a better estimation of gamma heating in experimental reactors and devices: Stakes and work plan from calculation methods to nuclear data. Journal of Nuclear Scient and Technology 2015; 52(9):1-9.

9. Atsuhiko M. Sukegawaa, Yoshimasa Anayamab, Flexible heat-resistant neutron and gamma-ray shielding resins, Progress in Nuclear Science and Technology 2014; 4:627630 .

10. M. Varvayanni, N. Catsaros, M. Antonopoulos-Domis. Evaluation of nuclear heating of small samples in a research reactor core. Annals of Nuclear Energy 2008; 35:1414-1420. 